\title{
Effects of weir construction on fish population structure in the River Erro (North of Spain)
}

\author{
R. Miranda*, J. Oscoz, P.M. Leunda, C. García-Fresca, M.C. Escala
}

Department of Zoology and Ecology, Faculty of Sciences, University of Navarra, Irunlarrea s/n, E-31080 Pamplona, Spain.

\begin{abstract}
In 1996, a compound gauging weir was built in Villaveta Township (Navarra, North of Spain) in the river Erro (Ebro River Basin). Before and after its construction, fish and physical and chemical variables were examined to determine weir's impact on the reach. Fish captured by electrofishing were measured (total length), and population density and length distribution of the species were estimated. Species diversity (Shannon's diversity index), dominance (Simpson's dominance index) and evenness were also calculated. The results revealed an increase in fish population density, especially in smaller specimens, but a decrease in the larger fishes. Substrate and shelter alterations could explain the observed variations in the fish community. In order to improve the consolidation of well-developed fish populations, the placement of great boulders and the restoration of the riparian vegetation are suggested.
\end{abstract}

Keywords : compound gauging weir, habitat modification, abundance, assemblage structure.

\section{Introduction}

The construction of water retention structure can create serious modifications to riverine habitats and, as a consequence, affect fish populations (Schlosser \& Ebel 1989, Jurajda 1995) and other biota in rivers (Jacobsen 1998, Pardo et al. 1998). River channelisation and the destruction of riparian and submerged vegetation are some of the main reasons for the decline of some fish populations (Lusk 1996). Moreover, these structures constitute an obstacle to fish migration (Lucas \& Frear 1997) and, as a result, affect population structure.

The main problem regarding the analysis of effects of human modifications of river systems is the absence of data from the affected reach prior to the alteration (Bain et al. 2000). The usual alternative is the comparison of the already altered section with other similar non-modified areas (Englund \& Malmqvist 1996, Fjellheim \& Raddum 1996, Pilcher et al. 2004).

\footnotetext{
* Corresponding author :
}

E-mail: rmiranda@unav.es
The aim of the present study was to compare the habitat character and size structure of the fish populations in the River Erro before and after the construction of a compound gauging weir (Fig. 1). to identify the most important changes in the fish fauna, to identify the probable reasons for these alterations, and to propose possible solutions for the optimal development of fish populations in the river.

\section{Material and methods}

A tributary of the River Irati, the River Erro is characteristic of the western Pyrenean Valleys, flowing for $48.5 \mathrm{~km}$ north to south, through the Erro River Valley (Navarra, Spain) and draining an area of approximately $214 \mathrm{~km}^{2}$ (Fig.1). River discharge is greatest from November to April, with winter maximums related to oceanic rains. These progressively decrease in importance during spring when melt-water replaces them.

The studied area is an iberian cyprinid zone (García de Jalón \& González del Tánago 1983) situated approximately $2.6 \mathrm{~km}$ away from the river confluence with the River Irati, where river slope was $0.29 \%$, ele- 

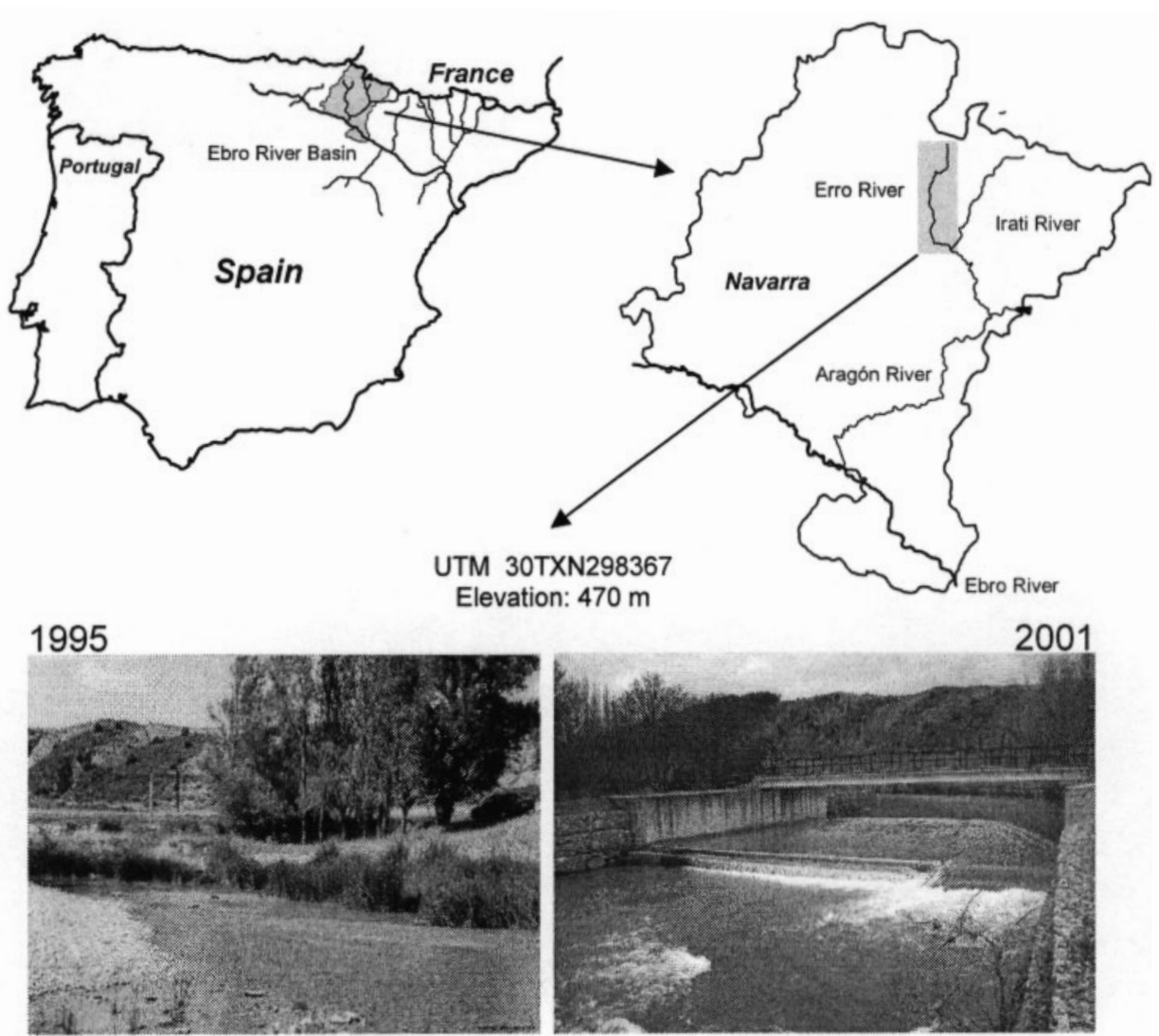

Fig. 1. Map of the Ebro River Basin and Navarra in the Iberian Peninsula (left) and the River Erro in Navarra (right). The pictures show the studied reach before (1995, left) and after (2001, right) the construction of the compound gauging weir.

vation 470 m.a.s.l. and the flooding width was about $375 \mathrm{~m}$ prior to weir construction.

The riparian vegetation of the sampling site was dominated by deciduous species (Salix sp., Populus nigra L.), with reed (Scirpus sp.) and bulrush (Typha sp.) constituting the emergent vegetation. During the construction of the compound gauging weir in 1996, the riparian and aquatic vegetation were removed.

Sampling was undertaken in the downstream reach of the compound gauging weir before (July 1995) and just after (August 1997) weir construction, and then in August 2001. The compound gauging weir consists of a $5 \mathrm{~m}$ long low flow section and a $16 \mathrm{~m}$ long high flow section.

Fish were captured by three-run depletion electrofishing between two stop nets (Lobón-Cerviá 1991). Fish collected on each run were processed separately. All the specimens were identified, measured (total length (TL) to the nearest $\mathrm{mm}$ ) and released into the river.
The same work-team and electrofishing gear were used in all surveys.

Nine habitat variables were measured along four transects using the transect-point method (Simonson et al. 1993) : water physical and chemicals (temperature $\left({ }^{\circ} \mathrm{C}\right)$, conductivity $\left(\mu \mathrm{S} \cdot \mathrm{cm}^{-1}\right)$, dissolved Oxygen $\left(\mathrm{mg} \cdot \mathrm{l}^{-1}\right)$ and $\mathrm{pH})$, water current velocities $\left(\mathrm{m}^{\cdot} \mathrm{s}^{-1}\right)$ at 0.6 depth, river width $(\mathrm{m})$ and depths $(\mathrm{cm})$, with substrate type and vegetation estimated visually.

Fish population estimates were made according to Lelek (1974), because of its simplicity and high precision (Lobón-Cerviá 1991). Fish densities for each species (number of specimens per $100 \mathrm{~m}^{2}$ ) and for each body length interval were also estimated. Subsequently, species diversity (Shannon's diversity index H'=$\sum \mathrm{p}_{\mathrm{i}} \log _{2} \mathrm{p}_{\mathrm{i}}$ ), dominance (Simpson's dominance index $\left.\mathrm{D}=\sum \mathrm{p}_{\mathrm{i}}^{2}\right)$ and evenness $\left(\mathrm{E}=\mathrm{H}^{\prime} / \log _{2} \mathrm{~S}\right)$ were calculated, where $\mathrm{pi}$ is the proportion of species «i» at a given site and $\mathrm{S}$ is the number of species (Margalef 1980). Al- 
Table 1. Habitat characteristics, physical and chemical variables measured in the sampling reach in 1995, 1997 and 2001. Substrate classes described by Platts et al. (1983). (-) Absent, (+) low, (++) moderate, (+++) very abundant.

\begin{tabular}{|c|c|c|c|c|c|c|c|}
\hline Physical \& chemical variables & 1995 & 1997 & 2001 & Substrate classes & 1995 & 1997 & 2001 \\
\hline Water temperature $\left({ }^{\circ} \mathrm{C}\right)$ & 21.9 & 21.4 & 23.4 & Fines $(<2 \mathrm{~mm})$ & - & - & - \\
\hline Conductivity $\left(\mu \mathrm{S} \cdot \mathrm{cm}^{-1}\right)$ & 435 & 475 & 403 & Gravel $(8-64 \mathrm{~mm})$ & - & + & + \\
\hline Oxygen $\left(\left.m g \cdot\right|^{-1}\right)$ & 9.9 & 9.95 & 9.43 & Cobbles $(64-256 \mathrm{~mm})$ & + & ++ & ++ \\
\hline $\mathrm{pH}$ & 7.96 & 8.33 & 8.23 & Boulders (>256 mm) & - & ++ & ++ \\
\hline Length (m) & 90 & 31 & 28 & Bedrock & +++ & +++ & +++ \\
\hline Width (m) & 11.03 & 17.73 & 21.45 & Pools & - & + & + \\
\hline Depth $(\mathrm{cm})$ & 22.0 & 15.5 & 21.17 & Riparian vegetation & + & - & - \\
\hline Area $\left(m^{2}\right)$ & 993 & 550 & 601 & Emergent vegetation & +++ & - & + \\
\hline Average velocity $\left(\mathrm{m} \cdot \mathrm{s}^{-1}\right)$ & 0.36 & 0.15 & 0.17 & & & & \\
\hline
\end{tabular}

though fish species reach different sizes and have different growth rates, the densities of all the species were pooled and compared in order to check whether a certain length class was favoured by the new habitat features.

\section{Results}

Physical and chemical variables of the water did not vary significantly during the study. Habitat features, however, experienced remarkable modification, most notably the destruction of riparian and emergent vegetation and the diversification of the substrate. Other changes implied the creation of shallow backwaters with low flow (Table I).

The fish assemblage was composed of three endemic Iberian species (Barbus graellsii Steind., Chondrostoma miegii Steind. and Cobitis calderoni Baces$\mathrm{cu}$ ) and four other native species (Salmo trutta L., Phoxinus phoxinus (L.), Barbatula barbatula (L.) and Gobio gobio (L.)).

Estimated total fish densities in 1997 and 2001 were respectively four and five times the density obtained in 1995 (Table II). Diversity decreased in 1997 (H'= $1.83)$ in relation to $1995\left(\mathrm{H}^{\prime}=2.00\right)$ and increased again in $2001\left(H^{\prime}=2.04\right)$. Something similar happened with the evenness index $\left(\mathrm{E}_{95}=0.71 ; \mathrm{E}_{97}=0.65 ; \mathrm{E}_{01}=\right.$ $0.79)$, and conversely with the dominance index $\left(\mathrm{D}_{95}=\right.$ $0.29 ; \mathrm{D}_{97}=0.34 ; \mathrm{D}_{01}=0.28$ ).

Overall, a decline in fish size was observed (Fig. $2 \mathrm{~A})$. Young $S$. trutta $(<110 \mathrm{~mm}$ TL) decreased in number after weir construction, and larger specimens appeared (Fig. 2B).

$P$. phoxinus total densities increased in 1997 compared with 1995, and smaller size classes showed a notable increase in 2001 (Fig. 3).

G. gobio and C. miegii densities increased substantially in all size classes after the construction (Fig.3), particularly medium sizes (40-80 mm TL for G. Gobio and 100-150 mm TL for $C$. miegii). In 2001, densities decreased but still were notably higher than in 1995 . Despite this, a remarkable increase in small sizes $(<40$ $\mathrm{mm}$ TL for G. Gobio and $<50 \mathrm{~mm}$ TL for $C$. miegii) was recorded.

Table 2. Number of fish captured (C), number of specimens estimated (N) according to Lelek (1974) and density of specimens per $100 \mathrm{~m}^{2}(\mathrm{~d})$ for each species and altogether.

\begin{tabular}{|c|c|c|c|c|c|c|c|c|c|}
\hline \multirow[t]{2}{*}{ Species } & \multicolumn{3}{|c|}{1995} & \multicolumn{3}{|c|}{1997} & \multicolumn{3}{|c|}{2001} \\
\hline & C & $\mathbf{N}$ & d & C & $\mathbf{N}$ & d & C & $\mathbf{N}$ & d \\
\hline Salmo trutta & 11 & 13 & 1 & 5 & 6 & 1 & 4 & 5 & 1 \\
\hline Phoxinus phoxinus & 261 & 298 & 30 & 243 & 270 & 49 & 1424 & 1735 & 289 \\
\hline Barbatula barbatula & 9 & 10 & 1 & 200 & 223 & 40 & 294 & 358 & 60 \\
\hline Chondrostoma miegii & 479 & 547 & 55 & 1184 & 1318 & 240 & 988 & 1204 & 200 \\
\hline Barbus graellsii & 191 & 218 & 22 & 79 & 88 & 16 & 244 & 297 & 49 \\
\hline Gobio gobio & 184 & 210 & 21 & 906 & 1008 & 183 & 523 & 637 & 106 \\
\hline Cobitis calderoni & 1 & 1 & 0 & 2 & 2 & 0 & 0 & 0 & 0 \\
\hline Total & 1136 & 1298 & 131 & 2619 & 2915 & 530 & 3477 & 4235 & 705 \\
\hline
\end{tabular}


A
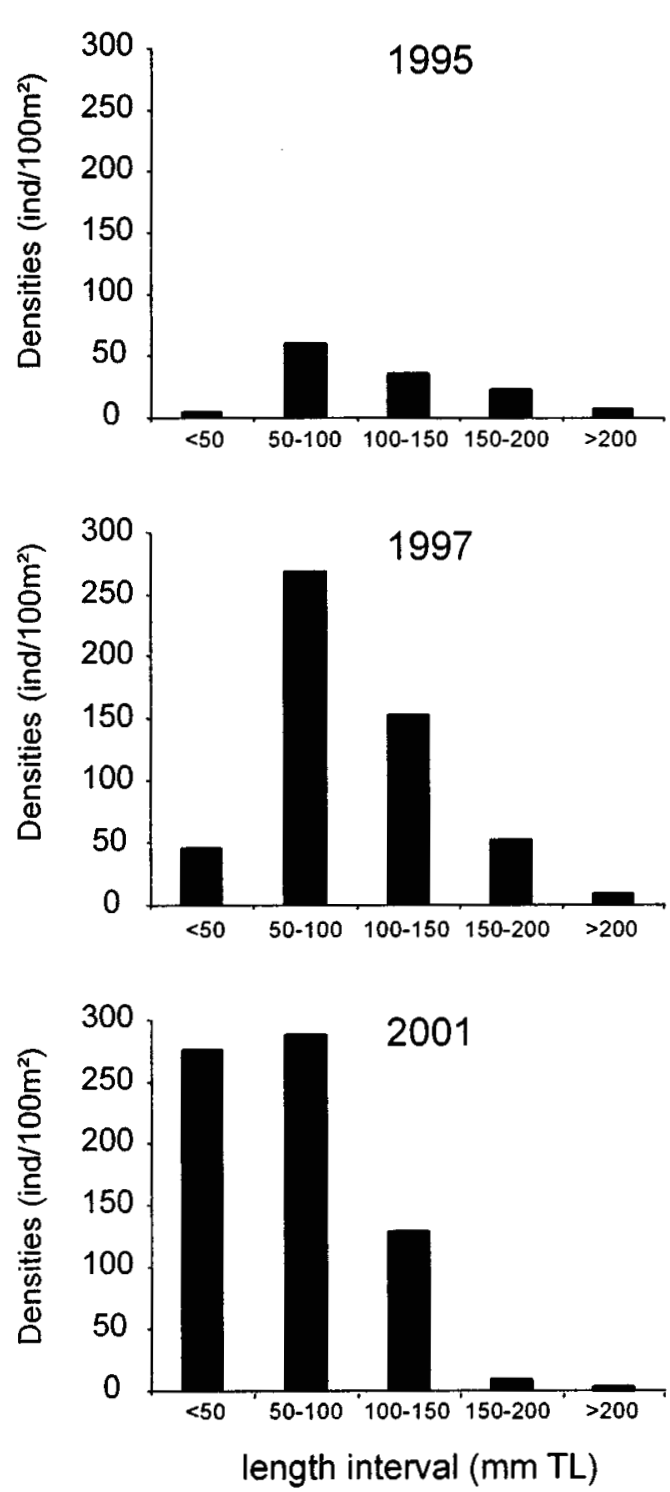

B Salmo trutta
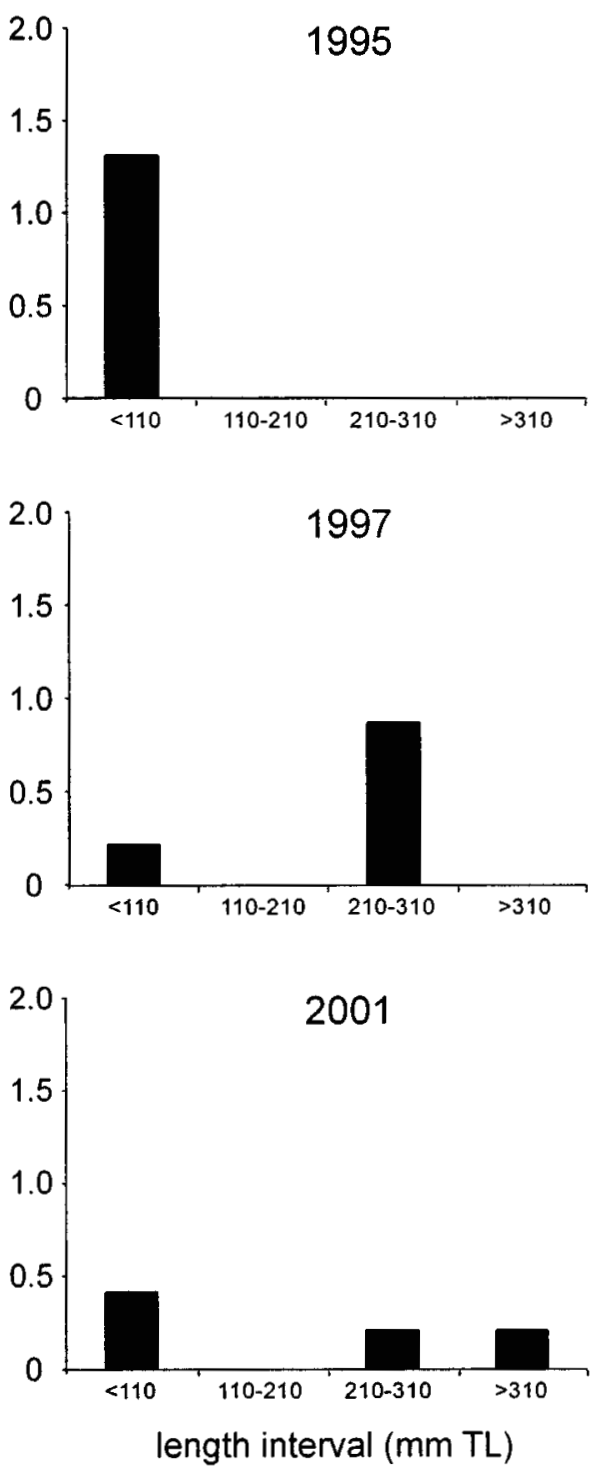

Fig. 2. Distribution of densities ( $\mathrm{N}$ of specimens per $100 \mathrm{~m}^{2}$ ) in each length interval (mm TL) for all the species as a whole (A) and Salmo trutta (B).

B. barbatula also underwent an important increase in 1997 (Table II) in all the size range in comparison with 1995 (Fig. 3). A new increase in total density occurred in 2001, mainly due to juveniles ( $<50 \mathrm{~mm}$ TL), in spite of the disappearance of the larger individuals.

In 1997, B. graellsii this species experienced a decrease in the total density, although larger barbels appeared (>350 mm TL). Nevertheless, in 2001 (Table
II) its density doubled the one in 1995 and was three times the 1997 value, due mainly to a large number of smaller fish (Fig. 3). On the other hand, the density of the individuals larger than $150 \mathrm{~mm}$ TL decreased throughout the study (Fig. 3). One specimen of $C$. calderoni $(\mathrm{TL}=52 \mathrm{~mm})$ was captured in 1995 , and two ( $\mathrm{TL}=36 \mathrm{~mm}, \mathrm{TL}=64 \mathrm{~mm}$ ) in 1997 surveys, but none were caught in 2001 . 

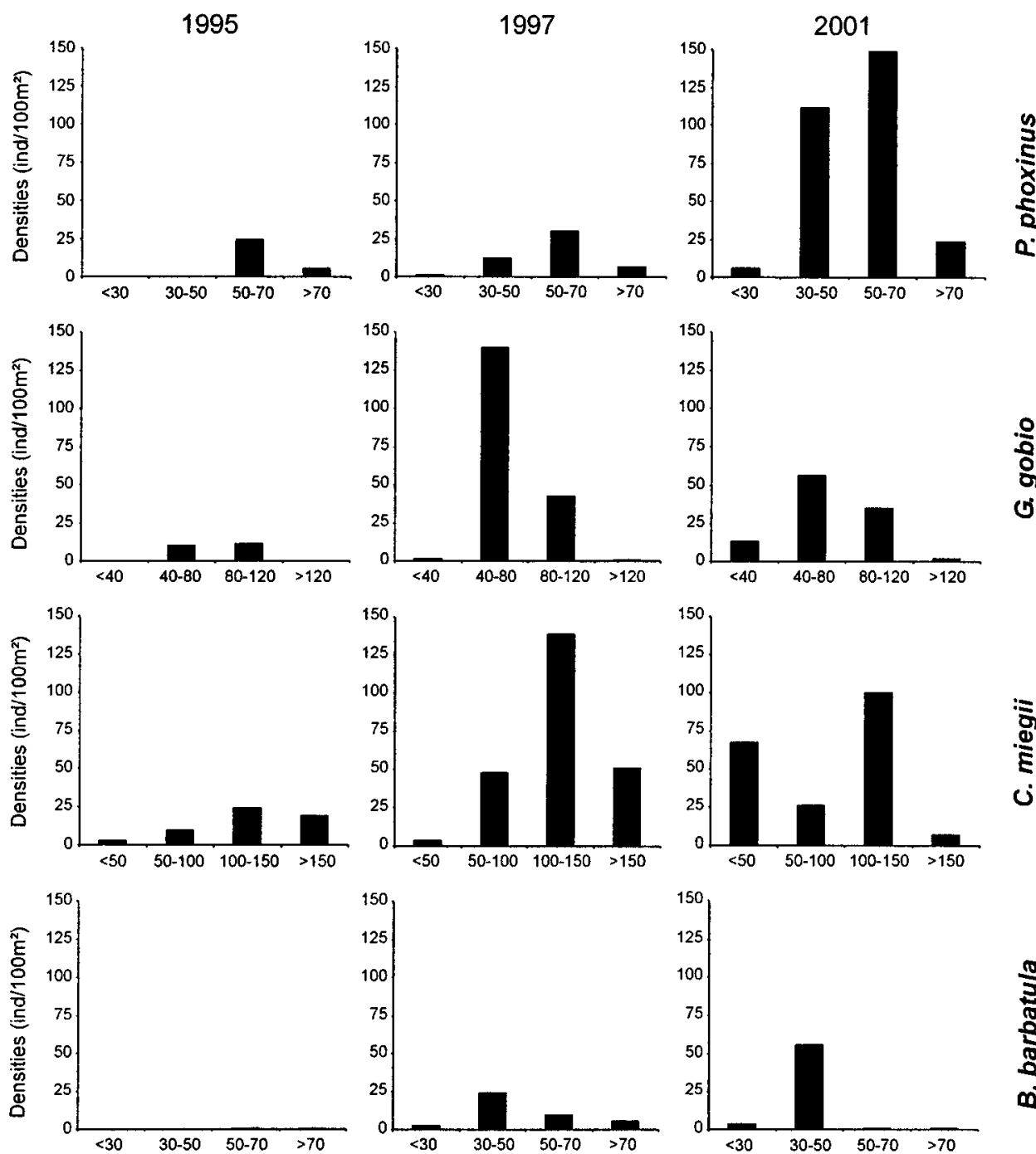

造
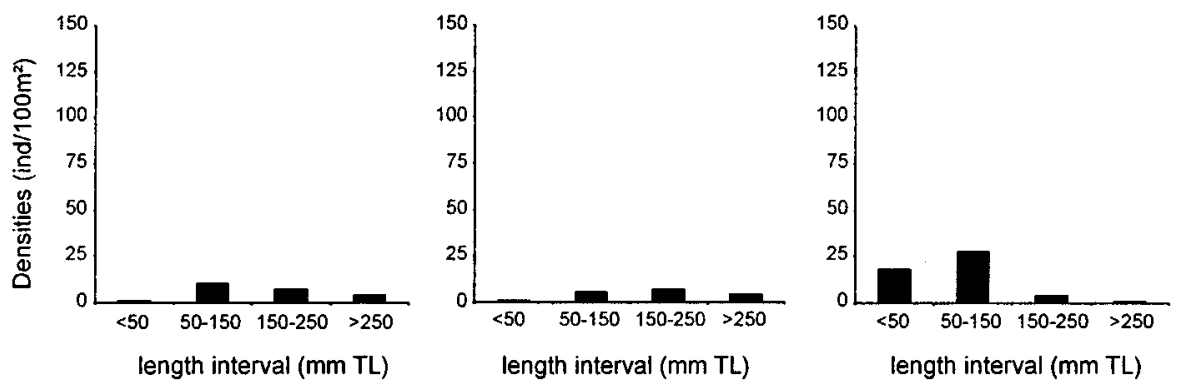

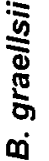

Fig. 3. Distribution of densities ( $\mathrm{N}$ of specimens per $100 \mathrm{~m}^{2}$ ) in each length interval (mm TL) for Phoxinus phoxinus, Gobio gobio, Chondrostoma miegii, Barbatula barbatula and Barbus graellsii. 


\section{Discussion}

Owing to the increase of G. gobio and C. miegii, which rapidly colonised the area, H', E and D indexes changed after the construction of the compound gauging weir (1997). However, in 2001 these indexes were similar to those in 1995 , as a result of the stabilisation of the affected reach.

S. trutta occurred in relatively low numbers throughout, but a shift to larger sizes was apparent (Table II, Fig. 2B). The disappearance of juveniles probably resulted from the elimination of emergent vegetation and woody debris (Langford \& Hawkins 1997), which provide potential shelter and nutrient concentration area for younger trout (García de Jalón \& Mayo 1996).

$P$. phoxinus underwent a remarkable increase throughout the studied period. The creation of shallow gravel areas with low current velocity could favour the spawning of the species in this reach (Mastrorillo et al. 1997, Mastrorillo \& Dauba 1999, Miranda et al. 1999) and the establishment of small individuals (Constantinescu et al. 1984, Rabeni \& Jacobson 1993).

Increase in the numbers of G. gobio and B. barbatula in 1997 may have resulted from substrate size diversification, with the appearance of cobbles, an important refuge for small benthonic fish (Mackenzie \& Greenberg 1998). Another factor might be the decrease of water velocity and depth, which favours the establishment of these species (Eklov et al. 1994, Zweimüller 1995, Mastrorillo \& Dauba 1999). Their generalistic nature and colonising capacity (Prenda et al. 1997) enabled the quick establishment of their populations after the construction. In 2001, the former species did not evolve in the same way. The competition and establishment of other fish species could explain the decrease of medium-sized G. gobio individuals (40-80 mm TL). And there is a notable increase in smaller B. barbatula (30-50 mm TL), probably due to the new features of the habitat fulfill species requirements (Mastrorillo et al. 1996), but with a decline in larger ( $>50 \mathrm{~mm} \mathrm{TL}$ ), perhaps due to the reasons mentioned for intermediate G. gobio.

C. miegii population responded in a similar manner as G. gobio, and possibly similar reasons could explain it. This is a lithophilous (Mann 1996) and detritivorous species, so the removal of emergent vegetation and the increase of the foraging surface might have facilitated the development of proper trophic resources.

In respect of $B$. graellsii, two different alterations were observed. On one hand, the disappearance of the largest individuals ( $>250 \mathrm{~mm} \mathrm{TL}$ ) might be explained by the elimination of suitable shelters (Linlokken 1997) and the increased shallowness (Copp \& Bennetts 1996). On the other hand, the remarkable increase in the number of young-of-the-year and juveniles $(<100 \mathrm{~mm}$ TL) may be due to the creation of optimum habitats for them.

The Iberian endemic C. calderoni (Doadrio et al. 1991) was captured in very low numbers in 1995 , disappearing from the studied reach after the construction of the compound gauging weir, suggesting that habitat modifications pushed this vulnerable species (IUCN 2002: VU A1ace+2ce) to local extinction.

Stream canalisation and the destruction of emergent vegetation are often related to decline in fish populations (Lusk 1996). But, in the present study the weir construction had a notable increase in the species density. The creation of new shelters (calm shallow areas and small pools) and the diversification of the substrate could explain the observed increment (Shields et al. 1998, Pilcher et al. 2004).

However, fish assemblage structure has been severely altered. Considering all the species together, the impressive increase of the smaller sizes $(<50 \mathrm{~mm}$ TL) might be because the studied stretch has become a typical breeding area for cyprinids: low depth, absence of plant cover, high exposure to the sun, low water velocity and suitable substrate, both for the development of macroinvertebrate communities and to provide shelter (Grossman et al. 1987, Schlosser \& Angermeier 1990, Rabeni \& Jacobson 1993, Pilcher et al. 2004). The compound gauging weir also might have a « crowding effect » on this size class.

In addition, the decrease of the largest B. graellsii, an endemic species of the Ebro River Basin (Doadrio et al. 1991), could be due to the elimination of suitable refuges, as mentioned above. This negative effect could be rectified with the placement of great boulders, which would create deep pools with woody debris (Linlokken 1997) and with the restoration of the native vegetation providing cover and shadow (Petts \& Calow 1996).

Acknowledgements

We thank J.M. Lekuona, P. Galvez, R. Aldaz, M. Serrano, L. Goñi, P. Echeveste, D. Usán, U. Otxotorena, P. Álvarez, J. García, E. Garayoa, G. Telletxea, M. Rodríguez, D. Galicia and J. Madoz for assistance with the electrofishing. This research was carried out as part of the project PIUNA titled «Estudio de la fauna piscícola de los ríos Erro, Larraun y Urederra (Navarra) » supported by the ICT and the Fundación Universitaria de Navarra, and the project «Actuaciones humanas en ríos de Navarra. Su incidencia en la conservación de la biodiversidad » supported by the CSIC and the Government of Navarra. 


\section{References}

Bain M.B., Harig A.M., Loucks D.P., Goforth R.R. \& Mills K.E. 2000. - Aquatic ecosystem protection and restoration : advances in methods for assessment and evaluation. Environ. Sci. Policy, 3, 89-98.

Constantinescu V., Vintila C. \& Damian S. 1984. - Contributions to the knowledge of the breeding coloration and behaviour in Phoxinus phoxinus (Pisces, Cyprinidae). Travaux du Museum d'Histoire Naturelle "Grigore Antipa », 25, 267-289.

Copp G.H. \& Bennetts T.A. 1996. - Short-term effects of removing riparian and instream cover on barbel (Barbus barbus) and other fish populations in a stretch of English chalk stream. Folia Zool., 45, 283-288.

Doadrio I., Elvira B. \& Bernat Y. 1991. - Peces continentales españoles (Inventario y clasificación de zonas fluviales). ICONA, Colección Técnica. Ministerio de Agricultura, Pesca y Alimentación, Madrid, 221 p.

Eklov A.G., Greenberg L.A. \& Kristiansen H. 1994. - The effect of depth on the interaction between perch (Perca fluviatilis) and minnow (Phoxinus phoxinus). Ecol. Freshwat. Fish, 3, 1-8.

Englund G. \& Malmqvist B. 1996. - Effects of flow regulation, habitat area and isolation on the macroinvertebrate fauna of rapids in north Swedish rivers. Regul. Rivers : Res. Mgmt., 12, 433-445.

Fjellheim A. \& Raddum G.G. 1996. - Weir building in a regulated west Norwegian river : long-term dynamics of invertebrates and fish. Regul. Rivers : Res. Mgmt., 12, 501-508.

García de Jalón D. \& González del Tánago M. 1983. - Estudio biotipológico de las comunidades piscícolas de la cuenca del Duero. Bol. Est. Cent. Ecología, 12, 57-66.

García de Jalon D. \& Mayo M. 1996. - Characterization of Spanish Pyrenean stream habitat : relationships between fish communities and their habitat. Regul. Rivers : Res. Mgmt., 12, 305-316.

Grossman G.D., de Sostoa A., Freeman M.C. \& Lobón-Cerviá J. 1987. - Microhabitat use in a Mediterranean riverine fish assemblage. Fishes of the lower Matarraña. Oecologia (Berlin), 73, 490-500.

IUCN Species Survival Commission, 2002. - The IUCN Red List of Threatened Species. http://www.redlist.org/.

Jacobsen D. 1998. - The effect of organic pollution on the macroinvertebrate fauna of Ecuadorian highland streams. Arch. Hydrobiol., 143, 179-195.

Jurajda P. 1995. - Effect of channelization and regulation on fish recruitment in a flood plain river. Regul. Rivers : Res. Mgmt., 10, 207-215.

Langford T.E. \&. Hawkins S.J. 1997. - The distribution and abundance of the fish species in relation to timber debris and meso-habitats in a lowland forest stream during autumn and winter. Limnetica, 13, 93-102.

Lelek A. 1974. - Toward a method of evaluation of fish populations in streams based on successive fish removals. Proceedings of Aviemore Symposium FAO. EIFAC/74/I/Symp, 38, 2-8.

Linlokken A. 1997. - Effects of instream habitat enhancement on fish populations of a small norwegian stream. Nordic J. Freshw. Res., 73, 50-59.

Lobón-Cerviá J. 1991. - Dinámica de poblaciones de peces en ríos. Pesca eléctrica y métodos de capturas sucesivas en la estima de abundancia. Museo Nacional de Ciencias Naturales C.S.I.C., Madrid, $156 \mathrm{p}$.
Lucas M.C. \& Frear P.A. 1997. - Effects of a flow-gauging weir on the migratory behaviour of adult barbel, a riverine cyprinid. J. Fish Biol., 50, 382-396.

Lusk S. 1996. - Development and status of populations of Barbus barbus in the waters of the Czech Republic. Folia Zool., 45 (suppl. 1), 39-46.

Mackenzie A.R. \& Greenberg L. 1998. - The influence of instream cover and predation risk on microhabitat selection of stone loach Barbatula barbatula (L.). Ecol. Freshwat. Fish, 7, 87-94.

Mann R.H.K. 1996. - Environmental requirements of European nonsalmonid fis in rivers. Hydrobiologia, 323, 223-235.

Margalef R. 1980. - Ecología. Editorial Omega, Barcelona, 951 p.

Mastrorillo S. \& Dauba F. 1999. - Short-term impact of reservoir cleaning on the microhabitat use of three non-salmonid fishes in a piedmont river in south west France. Aquat. Sci., 61, 323-336.

Mastrorillo S., Dauba F. \& Belaud A. 1996. - Utilisation des microhabitats par le vairon, le goujon et la loche franche dans trois rivières du sud-ouest de la France. Ann. Limnol., 32 (3), 185-195.

Mastrorillo S., Lek S. \& Dauba F. 1997. - Predicting the abundance of minnow Phoxinus phoxinus (Cyprinidae) in the River Ariege (France) using artificial neural networks. Aquat. Living Resour., 10, 169-176.

Miranda R., Campos F., García-Fresca C., Oscoz J., Escala M.C. \& Lekuona J.M. 1999. - Distribución de sexos del Piscardo (Phoxinus phoxinus) durante la época reproductora en un río del norte de España. Ecología, 13, 303-309.

Pardo I., Campbell I.C. \& Brittain J.E. 1998. - Influence of dam operation on mayfly assemblage structure and life histories in two south-eastern Australian streams. Regul. Rivers : Res. Mgmt., 14, 285-295.

Pilcher M., Copp G.H. \& Szomolai V. 2004. - A comparison of adjacent natural and channelised stretches of a lowland river. Biologia, 58, 669-673.

Petts G. E. \& Calow P. (eds.) 1996. - River restoration: selected extracts from the rives handbook. Blackwell Scientific Publications. VII, Oxford, $231 \mathrm{p}$

Platts W.S., Megahan W.S. \& Minshall G. 1983. - Methods for evaluating stream, riparian and biotic conditions. Intermountain Forest and Range Experiment Station, Ogden, 69 p.

Prenda J., Armitage P.D. \& Grayston A. 1997. - Habitat use by the fish assemblages of two chalk streams. J. Fish Biol., 51, 64-79.

Rabeni C.F., Jacobson R.B. 1993. - The importance of fluvial hydraulics to fish-habitat restoration in low gradient alluvial streams. Freshwat. Biol., 29, 211-220.

Schlosser I.J. \& Angermeier P.L. 1990. - The influence of environmental variability, resource abundance, and predation on juvenile cyprinid and centrarchid fishes. Pol. Arch. Hydrobiol., 37, 265284.

Schlosser I.J. \& Ebel K.K. 1989. - Effects of flow regime and cyprinid predation on a headwater stream. Ecol. Monogr, 59, 41-57.

Shields F.D., Knight S.S. \& Cooper C.M. 1998. - Rehabilitation of aquatic habitats in warmwater streams damaged by channel incision in Mississippi. Hydrobiologia, 382, 63-86.

Simonson T., Lyons J. \& Kanehl P.D. 1993. - Guidelines for evaluating fish habitat in Wisconsin streams. Gen. Tech. Rep. NC-164. St. Paul, MN: U.S. Department of Agriculture, Forest Service, North Central Forest Experiment Station, 36 p.

Zweimüller I. 1995. - Microhabitat use by two small benthic stream fish in a $2^{\text {nd }}$ order stream. Hydrobiologia, 303, 125-137. 